\title{
Acha (Digitaria exilis) Malt as a Source of Enzyme for Bio-Ethanol Production from Starchy Materials
}

\author{
Mulak N. K. ${ }^{1}$ and Ogbonna J . C. ${ }^{2}$ \\ ${ }^{1}$ Department of Microbiology, University of Nigeria Nsukka, Nigeria. \\ 2Department of Biology, Federal College of Education Pankshin, Plateau State, Nigeria.
}

(Received: 10:07:2015; Accepted: 06:12:2015)

\begin{abstract}
Three acha varieties were malted and their enzyme activities were compared with that of barley malt. During the malting, the maximum amylase activity was achieved on day 3 for white and black acha but in the case of brown acha, the maximum activity was obtained on day 4. Under the optima malting conditions, all the three acha varieties gave higher amylase activity than barley malt. Of the three varieties of acha, white acha gave the highest glucoamylase activity $(50 \mathrm{U} / \mathrm{ml})$ and the least was exhibited by barley malt $(26 \mathrm{U} / \mathrm{ml})$. Application of malted acha as a source of enzyme for simultaneous hydrolysis and ethanol fermentation of two substrates (cassava and com flour) was investigated under various conditions. Cassava flour yielded higher ethanol than com flour under all the conditions investigated. Comparison of acha malt with koji enzymes for simultaneous hydrolysis and ethanol fermentation under various conditions showed that acha malt enzymes are superior to koji enzymes (microbial enzymes) under the three conditions investigated. Furthermore, regardless of the substrate used, gelatinization of starch improved ethanol productivity and yields. Incubating a mixture of raw starch and acha malt at $50^{\circ} \mathrm{C}$ for 30 minutes before inoculation of yeast cells improved the ethanol production but the final ethanol concentration was not as high as the value obtained with gelatinized starch. These results have demonstrated that acha malt has great potential application in brewery and ethanol production industries.
\end{abstract}

Keywords: Acha malt, Koji enzymes, Bio-ethanol, Cassava flour, Corn flour

Correspondence: mulakke@yahoo.com

\section{Introduction}

The market for biofuels, especially fuel ethanol has been expanding worldwide due to their obvious advantages (renewability and environmentally friendliness) over fossil fuel. Most of the Sub-Saharan African countries have abundant biomass materials that can be efficiently converted into bio-ethanol. Yet, aside from South Africa, there is almost no large-scale fuel ethanol industry in the continent. A major problem militating against development of fuel ethanol industries in Africa is the high costs of acids, base or enzymes for the first stage of starch hydrolysis. Although these are relatively cheap in most developed countries, they remain expensive in Africa because there are no industries producing them locally (Oshelowo
2012). Thus they must be imported from other countries at relatively high costs. Micro organisms are the major source of enzymes in bio-ethanol industries but again there are no industries for local production of microbial enzymes in most African countries. Besides, depending on their formulation, they are easily deactivated at high temperatures prevalent in most African countries while instability in electricity supply makes storage at low temperatures difficult.

In brewing industries, malts, especially barley malts are used as the source of enzymes (Beta et al., 2004). Unfortunately, barley is a temperate crop and thus cannot be cultivated in most tropical countries. An attempt has been made to develop sorghum malts in Nigeria but 
the enzyme activity is still comparatively low and thus must be supplemented with either barley malt or microbial enzymes for improved efficiency (Akande and Olorunfemi 2009). There is therefore a need to investigate alternative sources of enzymes for brewery and ethanol production industries in Nigeria and other tropical countries.

Acha (Digitaria exilis) is probably the oldest African cereal. For thousands of years, West Africans have cultivated it across the savannas. Even though some people have never heard of it, this crop still remains important in certain regions of Nigeria, Mali, Burkina Faso and Guinea. It is either the staple or major part of the diet (Obizoba and Anyika, 2006). Acha is a small annual crop that grows to a height of $30-80 \mathrm{~cm}$ and it is cultivated in various parts of Nigeria (Philip and Itodo 2006). Acha is not a demanding crop and tolerates a wide range of soils. It is one of the world's fastest growing cereals, reaching maturity in as little as six to eight weeks (Bakare, 2005). The yield is also high even in poor soils. Unfortunately, production and consumption of acha is restricted because they are not well known and the taste and aroma are not as acceptable as those of rice and other tropical cereals. The aim of this work was therefore to evaluate the potentials of malting acha as a source of enzyme for bioethanol production.

\section{Materials and Methods}

Acha grains and barley malt: Three Acha (Digiteria exilis), ecotypes (white, black, and brown) were obtained from Vom, while barley malt was obtained from Jos International Brewery (J IB) both in Plateau State, Nigeria.

Malting of acha: Acha; (white, black, and brown) were cleaned and steeped in water for $24 \mathrm{~h}$ at room temperature $\left(\sim 27^{\circ} \mathrm{C}\right)$. After steeping, the grains were drained and spread on a germination tray for germination to take place. The moisture content was maintained by occasionally sprinkling distilled water on the grains using a sprinkler. Samples were withdrawn from each sprouting cereal at $24 \mathrm{~h}$ intervals up to 7 days. Each day, small samples were taken and germination was stopped by sun drying according to the method described by Mulak and Ogbonna; (2010).
Comparison of enzyme activities of the malts: The malted grain $(1 \mathrm{~g})$ was milled in $5 \mathrm{ml}$ of pre-chilled $0.05 \mathrm{M}$ citrate phosphate buffer (pH 6.0). The resulting homogenate was centrifuged at $3000 \mathrm{~g}$ for 10 minutes. The enzyme activities in the supernatant were assayed according to the method of Egwim and Oyelola; (2000). Glucoamylase was assayed by pippetting $0.1 \mathrm{ml}$ of the supernatant (crude enzyme) into a separate test tube, followed by addition of $0.9 \mathrm{ml}$ of $2 \%$ soluble starch. The test tube was then incubated in a shaking water bath at $27{ }^{\circ} \mathrm{C}$ for 30 minutes. The reaction was stopped by adding $3 \mathrm{ml}$ dinitrosalicylic acid (DNSA) reagent and boiling for 3 minutes for colour development. The absorbance was measured at 550nm against blank. The blank contained all the assay reagents without the enzyme. Glucose concentration in the reaction mixture was calculated using a standard glucose calibration curve. One unit of glucoamylase was defined as the amount of enzyme required to liberate one microgram of glucose per milliliters per minute $(\mu \mathrm{g} / \mathrm{ml} /$ minute) under the assay condition.

Preparation of cassava and corn flour: Cassava (Manihot esculenta) tubers and maize (Zea maize) grains were obtained from the experimental farm of the Department of Crop Sciences, University of Nigeria, Nsukka. The cassava tubers were peeled, washed with clean water and milled. The milled cassava was sieved and sun dried. In the case of corn flour, the com grains were washed, milled, sieved and sun dried.

Preparation of koji enzymes: One hundred grams of boiled rice was spread in a clean sterile cloth. Ten milliliters of sterile water was used to harvest spores from a slant of Aspergillus spp obtained from the Department of Microbiology, University of Nigeria. The spore suspension was inoculated into the rice and mixed properly for uniform distribution of spores. The cloth was then wrapped and incubated at room temperature for $24 \mathrm{~h}$, mixed and incubated again for another $24 \mathrm{~h}$ (total incubation period was $48 \mathrm{~h}$ ). The enzyme produced was used for hydrolysis of starch for ethanol production.

Use of malted acha for simultaneous hydrolysis and ethanol production from cassava and corn flours: Simultaneous hydrolysis and 
ethanol fermentation of cassava and com flour using malted acha was carried out under three different conditions.

(1) Acha malt $(2.5 \mathrm{~g}), 2.5 \mathrm{~g}$ of raw starch (cassava or com flour) and yeast cells were mixed together in $50 \mathrm{ml}$ distilled water and incubated at $27^{\circ} \mathrm{C}$

(2) Acha malt $(2.5 \mathrm{~g})$ and $2.5 \mathrm{~g}$ flour were mixed together in $50 \mathrm{ml}$ of distilled water and maintained at $50^{\circ} \mathrm{C}$ for 30 minutes, cooled and inoculated with yeast cells.

(3) A $2.5 \mathrm{~g}$ flour sample was gelatinized in $50 \mathrm{ml}$ distilled water, cooled at room

temperature, $2.5 \mathrm{~g}$ of acha malt was added and then inoculated with yeast cells.

The above preparations were fermented according to the method described by Odibo; et al; (2002), and Ochanda et al.; (2010) with modification. Each one of them was inoculated with $4 \times 10^{7}$ yeast cells and incubated for 7 days at room temperature. During the fermentation, ethanol and starch concentrations were determined at $12 \mathrm{~h}$ intervals. Similar experiments were performed using koji enzymes in place of acha malts.

Determination of ethanol concentration: Ethanol concentrations in the samples were determined using the method for determination of ethanol concentration in aqueous solution by Outreach College of Science University of Canterbury. To $250 \mathrm{ml}$ conical flask, $10 \mathrm{ml}$ of acid dichromate solution $\left(70 \mathrm{ml}\right.$ of $\mathrm{H}_{2} \mathrm{SO}_{4}$ in $125 \mathrm{ml}$ distilled water and $0.75 \mathrm{~g}$ of potassium dichromate were mixed and the volume made to $250 \mathrm{ml}$ with distilled water) was added with matching rubber stopper. One millilitre of the sample (culture broth) was pippetted into a $2 \mathrm{ml}$ sample holder. The sample holder was suspended over the dichromate solution and held in place with the rubber stopper. The flask was incubated for $24 \mathrm{~h}$ at room temperature $\left(25-30{ }^{\circ} \mathrm{C}\right)$. After the $24 \mathrm{~h}$, the sample was removed and discarded. One hundred millilitres of distilled water was used to rinse the flask and $1 \mathrm{ml}$ (1.2M) potassium iodide solution was added. The solution was titrated with $0.03 \mathrm{M}$ ( $7.44 \mathrm{~g}$ in $\mathrm{IL}$ ) sodium thiosulphate pentahydrate $\left(\mathrm{Na}_{2} \mathrm{~S}_{2} \mathrm{O}_{3} .5 \mathrm{H}_{2} \mathrm{O}\right)$ until the colour faded to yellow and $1 \mathrm{ml} 1 \%$ starch concentration was added and titration continued until the colour disappeared and the titre value recorded. The blank contained all the reagents without the sample. The concentration of ethanol was calculated using a calibration curve.

Determination of starch concentration: Starch concentration was determined following the method described by Bailey and Olis, (1986). One milliliter of the sample was mixed with $9 \mathrm{~mL}$ of $0.1 \mathrm{~N} \mathrm{HCl}$ and $0.5 \mathrm{ml}$ of the solution was mixed with $10 \mathrm{~mL}$ of I-KI colour reagent $(0.2 \%$ iodine in $2 \%$ potassium iodide). The absorbance of the mixture was read at $660 \mathrm{~nm}$ and the starch concentration was calculated from a calibration curve.

Statistical analysis: Results of the various experiments were statistically analyzed for differences, using Analysis of Variance (ANOVA) and the means were separated, using the Least Significant Difference (LSD).

\section{Results}

Comparison of enzyme activities of the malted acha varieties: Figure 1 shows changes in the amylase activities during the malting of white, black and brown acha varieties. Malted white and black acha had the maximum enzyme activity on day 3 , while brown acha had the maximum enzyme activity on day 4. In other words, the white and black acha should be germinated/sprouted for 3 days while the brown acha should be sprouted for 4 days for maximum amylase production. The maximum activities of amylase were 50, 39 and 30 for white, brown and black acha, respectively; which were significantly different $(P \leq 0.05)$. The enzyme activity in the barley malt obtained from J os Intemational Breweries was $26 \mathrm{u} / \mathrm{ml}$. Thus, the enzyme activities were ranked as (white acha $>$ brown acha $>$ black acha $=$ barley).

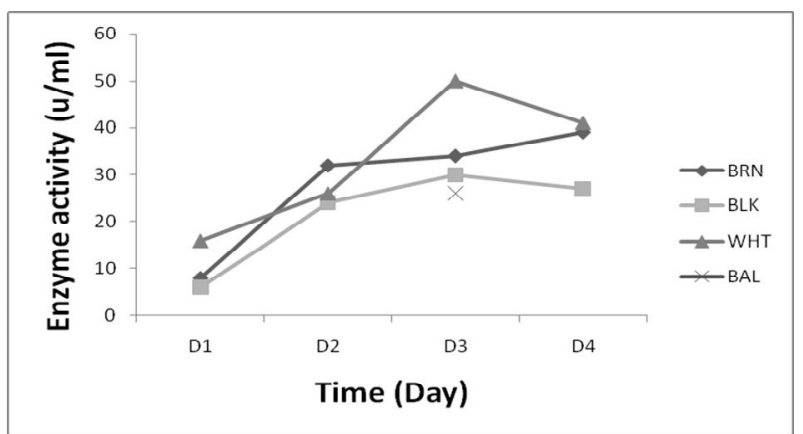

Figure 1: Changes in glucoamylase activities in acha during malting. BRN (Brown acha) BLK (Black acha) WHT (White acha) BAL (Barley) 
Comparison of white acha malt with koji enzyme for simultaneous starch hydrolysis and ethanol fermentation: Figure 2 compares the effects of enzymes from acha malt and koji on simultaneous hydrolysis and ethanol fermentation of the two substrates (cassava and com starch) pre-incubated at $50^{\circ} \mathrm{C}$ for 30 minutes before inoculation of yeast cells. The highest ethanol concentration was obtained when acha malt was used to hydrolyse cassava flour (2AC) while the least was obtained when koji was used to hydrolyse corn flour (7KM). Even at $27^{\circ} \mathrm{C}$ (Figure 3) and with gelatinized flours (Figure 4), use of acha malt on cassava flour resulted in the highest ethanol concentrations while koji enzymes gave the least ethanol concentrations.

The results of the statistical analysis showed significant differences between the two enzyme sources (acha malt and koji) in simultaneous hydrolysis and ethanol fermentation of the two substrates (cassava and com flour) $(P \leq 0.05)$. The ethanol concentrations $(\mathrm{g} / \mathrm{L})$ in the various combinations of acha malt with cassava flour pre-incubated at $50^{\circ} \mathrm{C}(2 \mathrm{AC})$, acha malt with corn flour pre-incubated at $50^{\circ} \mathrm{C}$ (2AM), koji with cassava flour pre-incubated at $50^{\circ} \mathrm{C}(7 \mathrm{KC})$, koji with corn flour pre-incubated at $50^{\circ} \mathrm{C}(7 \mathrm{KM})$, acha malt with cassava flour at $27^{\circ} \mathrm{C}(3 \mathrm{AC})$, acha malt with com flour at $27^{\circ} \mathrm{C}$ (3AM), koji with cassava flour at $27^{\circ} \mathrm{C}(8 \mathrm{KC})$, koji with corn flour at $27^{\circ} \mathrm{C}(8 \mathrm{KM})$, acha malt with gelatinized cassava flour ( $4 A C)$, acha malt and gelatinized com flour (4AM), koji with gelatinized cassava flour (9KC) and koji with gelatinized corn flour (9KM) were 1.23, 1.53, $0.77,0.89,0.85,0.93,0.77,0.81,2.52,2.55$, 0.79 , and 0.86 , respectively. Statistically, these ethanol concentrations are ranked as (4AM, $4 \mathrm{AC})>(2 \mathrm{AM}, 2 \mathrm{AC})>(3 \mathrm{AM}, 3 \mathrm{AC}, 7 \mathrm{KM}, 9 \mathrm{KM}$, $>(8 \mathrm{KM}, 9 \mathrm{KC}, 7 \mathrm{KC}, 8 \mathrm{KC})$.

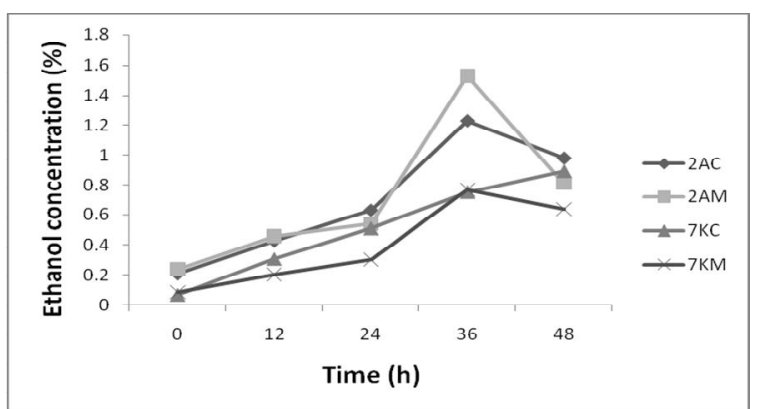

Figure 2: Effectiveness of acha malt and koji for simultaneous starch hydrolysis and ethanol fermentation of raw cassava and corn starch pre-incubated at $50^{\circ} \mathrm{C}$ before inoculation of yeast cells. The ratio of enzyme source to starch was $1: 1$, while the total starch concentration was $10 \%(\mathrm{w} / \mathrm{v})$. Acha malt and cassava starch (2AC), Acha malt and corn starch (2AM), Koji and cassava starch (7KC), Koji and corn starch (7KM).

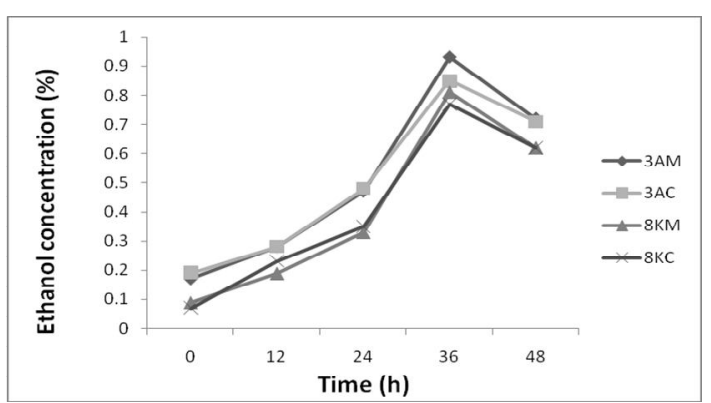

Figure 3: Effectiveness of acha malt and koji as sources of enzymes for simultaneous hydrolysis and ethanol fermentation of raw starch at $27^{\circ} \mathrm{C}$.

The ratio of enzyme source to starch was 1:1, while the total starch concentration was $10 \%(\mathrm{w} / \mathrm{v})$. Acha malt and cassava starch ( $3 A C)$, Acha malt and corn starch (3AM), Koji and cassava starch (8KC), Koji and corn starch (8KM)

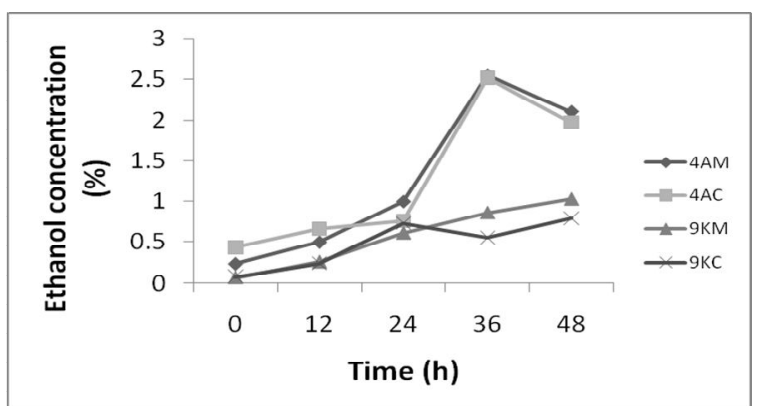

Figure 4: Effectiveness of acha malt and koji as sources of enzyme for simultaneous hydrolysis and ethanol fermentation of gelatinized cassava and corn starch at $27^{\circ} \mathrm{C}$.

Acha malt and cassava starch(4AC), Acha malt and com starch(4AM), Koji and cassava starch (9KC) and Koji and corn starch(9KM) 


\section{Discussion}

Enzyme activities in malts are affected by many factors such as the type and condition of the cereal, humidity, temperature and other environmental conditions during the malting as well as the duration of germination (Mulak and Ogbonna, 2010). In the present study, the optimum amylase activity was obtained on day 4 for brown acha, and day 3 for white and black acha. The peak values obtained at the end of germination is in agreement with the values reported by (Helland et al., 2002; Traore et al., 2004). They reported alpha amylase activities (ceralphaU/g DM) of 45,30 and 20 for red sorghum, Millet, and Maize, respectively. Although the amylase activities of the malts are affected by the quality of the raw material (variety, origin of the seeds, storage condition etc), the present study has shown that white acha gave the highest enzyme activity and thus has good potentials for simultaneous starch hydrolysis and ethanol production. (Nzelibe and Nwasika 1995) also reported that acha malt was better than both sorghum and millet malts in brewing. In the present study, acha malt was better than barley malt in terms of enzyme activity. However, in the case of brewing, aside from enzyme activities, other characteristics such as the effects of malts on the aroma and taste of the final product must be considered. Barley malt is extensively used for brewing and the aroma and taste are well accepted. Thus, it is necessary to also evaluate the aroma and taste of beer brewed with acha malt. Nevertheless, since acha yields very well even in poor soils and it is the fastest growing cereal reaching maturity in about six to eight weeks, it has very high potential at least in ethanol production industries in the tropics where barley does not grow.

Use of malted acha for simultaneous hydrolysis and ethanol fermentation of the two substrates under various conditions showed that the ethanol concentrations increased with increase in fermentation time and was highest with gelatinized starch (4AC and 4AM). Many previous reports have also shown that gelatinization improves hydrolysis (Baks 2007, Bamforth 2003, Bialas et al., 2014). The differences among the ethanol concentrations obtained from raw starch, raw starch preincubated at $50^{\circ} \mathrm{C}$ for 30 minutes, and gelatinized starch may be explained by considering the granule structure and the specific surface area of the granules (Powalowska, et al., 2012).

Comparison of acha malt with koji enzymes for simultaneous hydrolysis and ethanol fermentation under various conditions showed that acha malt enzyme is superior to koji enzyme (microbial enzymes) under the three conditions investigated. The superiority of acha malt over koji enzymes may be because of the high $\beta$-amylase content as reported by (Nzelibe and Nwasika 2007) which is the major starch degrading enzyme in acha (Digitaria exilis) but usually not present in Aspergillus species used for koji preparation in the present study. The result also agreed with (Nzelibe, 2001) which showed that the combination of alpha and beta amylase activities degraded starch faster and more completely than either alone. Nevertheless it will be hasty to conclude that acha malt is better than microbial enzymes since microbial enzyme activity depends a lot on the strain of microorganism used.

In conclusion, the present study has demonstrated the potential of acha malt as a source of enzyme for ethanol and brewery industries. This has a very serious implication in development of bioethanol and other industries based on hydrolysis of starch in Africa and other tropical countries.

\section{References}

Akande, S. O. and Olorunfemi (2009). Researh and development potentials in biofuels production in Nigeria. An Intemational MultiDisplinary J ournal, Ethopia 3 (3):34-45

Bailey, J. E., and Olis, D. F. (1986). Biochemical Engineering Fundamentals. Second edition, McGrew-Hill, 270-277.

Bakare S. O. (2005). influence of time of harvest on grain yield of Acha (Digiteria exilis) and farmers perspectives. International Joumal of Agriculture and Rural Development 6 132-135.

Baks Tim (2007) Process development for gelatinisation and enzymatic hydrolysis of starch 
at high concentrations.Wageningen University Research 2 3-4.

Bamforth Charles W. (2003). Barley and malt starch in Brewing: Ageneral review vol. 40 no. 2 pp 89-97.

Beta Trust, Rooney Lloyd W., and Waniska Ralph D. (2004). Malting characteristics of sorghum cultivars. American Association of Cereal Chemist 72533 - 537.

Bialas Wojciech, Czemiak Adrian and Powalowska Daria Syzmanowska (2014). Kinetic modeling of simultaneous saccharification and fermentation of com starch for ethanol production. ABP Biochimica polonica

Buzzle.com (2010). Biofuel production process .http://www.Buzzle.com/boards.asp

Egwim, E.C., Oloyede, O.B. (2006). Comparison of _-amylase activity in some sprouting Nigerian cereals. Biokemistry. 18(1): 15-20.

Helland M. A., Wickland T. and Navhus (2002). Effect of germination time on alpha-amylase production and viscosity of maize porridge. Elsevier J oumal of Food Research 35315 - 321.

Konsoula, Z., Liakopoulou-Kyriakides, M.(2006). Starch hydrolysis by the action of an entrapped in alginate capsules alpha amylase from bacillus subtilis. Process Biochemistry 41 343-349.

Mulak Nicodemus K. and Ogbonna J. C. (2010). Malting characteristics of Acha (Digitari exilis) and its potential in brewing. Proceeding of the $18^{\text {th }}$ annual conference/workshop of Foundation for African Development through Intemational Biotechnology.

Nzelibe Humpbrey C., and Nwasike C. C. (2007). The brewing potential, of 'acha" (Digiteria exilis) malt compared with pearl millet (pennisetum typhoides) malt and sorghum (sorghum bicolor) malts. Journal of the Institute of Brewing 101 $345-350$.
Nzelibe Humphrey C., Obaleye Sarah and Oyenekwe Paul Chidozie (2000). Malting characteristics of different varieties of fonio millet (Digiteria exilis). Journal of Science, Food and Agriculture 34: 461-463.

Obizoba J.C. and Anyika J.U. (2006).Nutritive value of baobab milk (gubdi) and mixtures of baobab (Adansonia digitata I.) and hungry rice, acha (Digitaria exilis) flours. Journal of Science, Food and Agriculture 56 561-563.

Ochanda, S. O., Onyango C. A., Mwasaru A. M., Ochieng J. K., and Mathooko F.M. (2010). Effects of malting and fermentation treatments on group B-vitamins of red sorghum, white sorghum and pearl millets in Kenya. Joumal of Applied Biosciences 34: 2128 - 2134

Odibo F. J. C., Nwankwo L. N., and Agu. R. C. (2002). Production of malt extract and beer from Nigerian sorghum varieties. J. Process Biochemtistry 37851 - 855 .

Oshelowo Segun (2012). Designed to fail? Nigeria's quest for biofuel. Afro Asian journal of Social Sciences Volume 3, No 3.3

Powalowska Daria-Szymanowska, Lewandowicz Grazyna, Blaszczak Wioletta, Szwangiel Artur (2012). Structure changes of corn starch during fuel ethanol production from corn flour. Joumal of Biotechnology vol. 93 (3) pp 333-341.

Philip T. K., and Itodo I. N. (2006). Acha (Digitaria exilis spp) a "Rediscovered" Indigenous crop of West Africa. Agricultural Engineering Intemational: the CIGR Ejoumal 23 7.

Traore T., Mouquet C., Icard - Verniere C., Traore A. J. and Treche S. (2003). Changes in nutrient composition, phytate and cyanide contents and alpha - amylase activity during cereal. Malting in small production units in Ouagadougou (Burkina Faso) J. Food Chemistry 10: 032. 